\title{
The Post-Human Media Semblance: Predictive Catastrophism
}

\author{
Ekin Erkan \\ The New Centre for Research \& Practice
}

Abstract: Since the advent of media archeology, a deep-seated bifurcation has found one end of the field arguing for the interventionist and appropriative weaponization of media whereas the other side has championed a "total war" with technology itself, insisting that new media's military-industrial roots inherently color its drivability. Here, I implore a moment within the cultural history of net.art and post-internet art to examine how contemporaneous queries about control after militarism and decentralization, as prognosticated by Paul Virilio and Gilles Deleuze, are part of a more deeply entrenched discourse on neural nets, predictive processing algorithms and machine learning, which the current media theory and post-cinema literature has yet to rigorously respond to. Simultaneously parsing philosophical and media sociology corollaries to ground this overview, I push for more attention towards psychopower, autosurveillance and algorithmic governmentality while distancing critique from the standard Foucauldian discourse of biopower.

\section{Introduction: the Intimacy of Moving through Virtual Images}

Over the last thirty years, the field of media studies has seen a significant perturbation. Once staunchly historical cinema scholars such as Thomas Elsaesser, Jusi Parikka, Siegfried Zielinski, André Gaudreault and Benoît Turquety (to name just a few) have abandoned history for historiography and film studies for media archaeology. With increasing attention on decentralization, Lev Manovich's "database" as a symbolic metaphor (1999), and the reticulated, networked tenants of the postmodern global present (Jameson 1934, 16), cinema, one of the last vestiges of the communal ritual, is taking on the characteristics of new media, existing in increasingly intertextual space (Daly 2010, 81). Thus, the term "post-cinema" has been co-opted as a viable intermediary that accounts for new media conditions, as "cinema" is no longer emblematic of our cultural climate nor is it tied to a material nexus. As Giorgio Agamben wrote in 1992, "[t]he end of the cinema truly sounds the death knell of the ultimate metaphysical adventure of Dasein. In the twilight of post-cinema, of which we are seeing the beginning, human quasi-existence, now stripped of any metaphysical hypostasis and deprived of any theological model, will have to seek its proper generic consistency elsewhere" $(2014,23)$. Accordingly, we are no longer "moviegoing animals" who seek images of ourselves among a collective in the dark (Agamben 1995), but, rather, users interfacing within a network of moving images.

By locating post-cinema within the semblance of platform capitalism, we are seemingly allocated a newfound series of politically galvanized theoretical interventions, the most marked of which is that of media archeology visà-vis dialectic materialism. Chris Milk and a slew of researchers working in the digital humanities have celebrated Virtual Reality as the actualization of the cinematic "empathy machine" that Roger Ebert once notably envisaged 
(Schutte and Stilinović 2017). In response, many media historians respond that, despite technological novelty, the ontological paradox of dialectical historicity is premised on an open Whole that is irremediably ruptured by its own absolute negativity. Thus glistens their Hegelian fervor and Marxist critique-one such theorist is Brian Winston who steadily maintains that the basic illusionism of all "technologies of seeing" is in disguising their artifice, their cultural formation and their ideological import (Winston 1996, 118). Winston's antipathy is reminiscent of Theodor Adorno and Max Horkheimer's oft-quoted 1944 essay, "The Culture Industry," which describes a profound and dangerous transformation of Western societies due to developments in the industry of cultural goods, which the pair foresaw would be accompanied by a "new kind of barbarism." If the unique work produced some kind of "cult value," its technological reproducibility resulted in "exhibition value," associated with the social act of viewing as part of a mass (Benjamin 1937). As post-cinema is no longer tied to the public act of viewership, it reifies platform capitalism's individualist impulse for autonomous and highly performative interaction; the "viewer" is not only perceptually transfixed in this performance but made into an ontologically engaged co-actor, converted into a "viewser" (a neologism of viewer + user).

Speaking to the intimacy of platform capitalism, Benjamin Barber, in Strong Democracy, foresaw new media's twofold potential-as they are organized and networked, new media and communications technologies possess the possibility to both energize citizen information and political participation but, simultaneously, to also supplement the deterioration of public debate $(1984,47)$. This two-pronged possibility has only been exacerbated by the interlocking relationship between the advent of information "glut," post-truth politics, the demise of symbolic efficiency, and a renewed focus on the role of affect and emotion as "alternative modalities for thinking about the role of communication in a post-referential era" (Andrejevic 2013,264). With sentiment analysis and data mining extricating emotion as recyclable and instrumental information, the scene is set for post-cinema viewership to lapse into a highly profitable, albeit veiled, capitalist endeavor. What, then, is to be said for resistance?

It's true that, even before control societies are fully in place, forms of delinquency or resistance (two different things) are also appearing. Computer piracy and viruses, for example, will replace strikes and what the nineteenth century called 'sabotage' . . You ask whether control or communication societies will lead to forms of resistance that might reopen the way for a communism ... The key thing may be to create vacuoles of noncommunication, circuit breakers, so we can elude control. (Deleuze 1990, 175)

As Deleuze notes in this quote from his interview with Antonio Negri and a 1990 article, "Postscript on Societies of Control," it would appear that today's ludic consumerist capitalism radically reshapes biopower, ushering in a third chronological period defined by computer technologies and immaterial digital labor. Abstract and diffuse, that which Bernard Stiegler terms "psychopower" follows the decentralized control of the prison and the factory. It would appear that Foucault was aware of a coming shift in the way biopower operates and, retrospectively, we can see this in the trajectory of Discipline and Punish (1975). In the very beginning of Foucault's text, we are introduced to Robert-François Damiens (also professedly known as "Damiens the Regicide") at his execution for parricide in $1774{ }^{[1]}$ Foucault guides us with great detail through a period characterized by the abrupt abandonment of judicial violence as a public ritualized event and its removal/relocation to invisible sites.

These invisible sites have, in an act of linguistic slippage, become epitomized by the "sites of the web," where Foucauldian contemporaries like Stiegler and Han Byung-Chul have located the "digital panopticon." Reliant on economies of data, digital industries function by tracking and capturing the activity of web users - for pervasive mobile media technologies, tracking and self-tracking, in particular, produce tacit knowledge that is rendered usable. Such information, which mediates processes and decisions, can be sourced from "direct process 
information" (also called "sematectonic information"), which emerges in and alongside digital activity and is opposed to indirect or marker-based information. While interpersonal information can be exchanged, transpersonal coordination is the product of mediation - thus a new socio-economic stasis has burgeoned with the decentralized "internet of things," in which an interwoven system of telecommunications forms an arachnean web; like electrical grids, computational machines have grown to span continents and the "digital turn" has extended the cartographic purview of virtualization to the molar scale of smart cities, undersea cable networks and satellite communication systems.

For occupants within the latticework of this "digital panopticon," total control comes about not through spatial communicative isolation but through networking and hypercommunication, the tenets of "psychopower." Foucault introduced the concept of "biopower" to help explain the power to interpret material objects as information, to affect objects at the statistical or informational level, not at the level of individual content. Psychopower, however, is globalized and diffracted, much like the flow of modulation, as it encompasses the systematic organization of the capture of attention made possible by the psychotechnologies that have developed with radio (1920), television (1950) and digital technologies (1990). As opposed to the "mob," the digital "swarm's" movement is not solely organized as a network, but possesses features radically distinct from those of the "crowd." The "swarm" is comprised of what Deleuze termed "dividuals," or isolated individuals rendered as data-entry points. Unlike the "mob," the "swarm" does not proclaim "we," but, instead, is comprised of a manifold abundance of "I's."

Manuel Castells qualifies Benjamin Barber's pessimism, noting that the Internet can "be an appropriate platform for informed, interactive politics, stimulating political participation... beyond the closed doors of political institutions," but that the Internet, like any technology, "is shaped by its uses and users" (Sey and Castells, 363). For Castells, within the schema of neoliberal globalization it is those who refuse to lapse into the digital swarm, or those "who are unable or unwilling to participate in any of the circuits of redistribution and networks of exchange" (124) who are increasingly marginalized. Thus, Castells and Stiegler are in agreement in regard to new media's token two-fold function as pharmakon, or as poison and cure.

Whereas communication is an orally-directed game, played between two interlocutors, the "swarm" produces the verbal cacography of noise in a contrapuntal matrix that, to the naked eye, is indeterminate in number. Thus, the perceptual faculty of Big Data's algorithmic governmentality is capable of parsing that which can be deemed extrahuman, superimposing sapience upon sentience to discern markers of excess, which will serve as predictive probabilism's input(s).

It is critical that we discern the mass of the "swarm" from McLuhan's "mass man" of Homo electronicus, the previous incarnation of the "electronic citizen... whose private identity has been psychically erased" (McLuhan and Nevitt 1975, 16). Today, in contrast, the networked Homo digitalis is anything but a "nobody," whose privacy is erased. Despite the fact that he takes the stage anonymously, the "mass man "of the contemporaneous Homo digitalis is tracked and surveilled ad infinitum. To the human observer, she is part of a grouped relay of digital individuals ("dividuals") found within the ludic, nonbinding carnivalesque space of cacophony. Empire, however, armed with the elastic faculties of predictive processing, can decipher this noise for information. "Empire is a mere apparatus of capture that lives only off the vitality of the multitude," (Negri and Hardt 2000, 62) and Empire's apparatus of choice is meta-data collection by way of algorithmic parsing. The dominating behavioral mode for the trans-individuated "swarm" is "autoexploitation," as control society reaches its completion when its inhabitants communicate out of some inner need rather than due to external constraints. 
Nonetheless, the reticulated nature of the virtual permits political potency and the language of Empire does not account for the winnowing of such sensory-neural possibilities. As exemplified by the networked nature of the Continental Direct Action Network (DAN) in North America, or the Movement for Global Resistance (MRG) in Catalonia, platform capitalism has provided political possibility for the bedrock of militant protest, as networks become the forum for symbolic exchange. In such instances, the horizontal, directly democratic process through which direct actions are organized - which include decentralized coordination among "autonomous affinity groups" and the prevailing "diversity of tactics" ethic among many activists-embody a broader cultural logic of the commons (Juris 2004, 346). The delineation between the economically-motivated bilocalization of data-collection and data's implementation for intelligence purposes becomes further and further blurred as the brute constraints of spatiotemporal mechanization increasingly define the sensory-neural conditions for predictive possibility as it concerns superintelligence (as in the case of Algorithmic Generalized Intelligence; Negarestani 2018, 167). In kind, the "network effect" is propelled by the self-production of traces, user profiling and real-time supercomputing, producing what Thomas Berns and Antoinette Rouvroy have termed "algorithmic governmentality," whereby multiple new automatic systems model a "social reality" built on statistical aggregation, analysis, and correlation afforded by Big Data $(2013,163)$. As Jonathan Crary evinces, the algorithmic governmentality of " $24 / 7$ capitalism" leads to what Freud denoted as "artificial crowds" (2003), where generalized human life is inscribed into duration without breaks and defined by a principle of continuous functioning (and sleeplessness). If cinema induces the externalization of noesis, of dreams made materially manifest, then platform capitalism parasites these dreams, reducing the "dream factory's" once-lauded idealism to the level of informatics. Emphasizing the elastic processability of topological combinatorics and stochastic logic (e.g. Markov chains, Bayesian neuro-inference, Chu spaces), where contingency is a function of game and chaos theory, post-cinema's narratology reflects and reasserts the logic of actuarial computation (thus the popularity of what Thomas Elsaesser terms the "mind-game film," a film genre/phenomenon poised along predictability, or a lack thereof, as it is characterized by unreliable narrators, hyper-text looping, and self-referential cues; Elsaesser 2008). As I hope to make evident, however, this is by no means a new phenomena, as it is politically prefigured by the proto-accelerationist theoretical discourse of net.art/post-internet art culture, listservs and artifacts.

\section{Pharmacological New Media}

Fredrich Kittler used the term psychophysics to describe the new technological media stored in the "discourse network of 1900" based on randomness and combinatorics. Whereas Kittler's "1800 kingdom of sense" corresponded to Foucault's sovereign societies and biopolitics, Kittler's "1900 kingdom of pattern," based on images and algorithms, corresponds to Deleuze's control society, though Kittler stalks this development's proleptical conception (Kittler 1990, 192, 206, 211-212). Kittler chose the epochal period of 1900 specifically because of the development of the phonograph and typewriter, where the ability to record sense-data technologically shifted - "[f]or the first time in history, writing ceased to be synonymous with the serial storage of data...the real entered into competition with the symbolic" (229-231). However, Kittler's description omits that this transformation is not only the conversion of matter into code, or the passage from the qualitative to the quantitative, but also a progression from the non-aesthetic to the aesthetic. ${ }^{[2]}$ This transition, from nonmedia to media, politicizes life while converting life into a socialized object, and nowhere is this more obviously the case than with the moving image.

As Deleuze's prescient remark to Antonio Negri in "Control and Becoming" reminds us, sites of control can also function as sites of resistance, or as pharmakon. Thus, while Foucault paints the prison as the locus for biopower, 
prison protest was also once the epitomal symbolic site for structural change-"[i]t is the prisons themselves that put up a resistance" (Bert 2012, 161). As Deleuze remarks in his book Foucault, "[w]hen power becomes bio-power resistance becomes the power of life, a vital power that cannot be confined within species, environment or the paths of a particular diagram" $(1996,92)$.

Similarly, new media objects now occupy this double-edged position for concealing control while invigorating resistance. New media's pharmacological value, however, is not simply limited to the terrain of post-cinema but instead has long facilitated a rhizomatic collaborative treatise. New media objects have been never been circumscribed as "apolitical," as I shall further expound on by illuminating the counter-culture ethos of "net.art" and what Geert Lovink calls "interventionist media." However, given the contemporaneous decline of symbolic efficiency (Žižek 1997, 232) in a "post-deferential" internet information-age brimming with "information glut" (Andrejevic 2013), the erosion of the boundary between the "real and the virtual" (Turkle 1997, 39), data-mining sociality, sentiment analysis, and the post-9/11 generalization of "total surveillance," skepticism has besmirched the once-lauded utopic, radical potential for an internet "marked by openness." Thus, unfolds what post-internet art has long realized and post-cinema discourse is just newly contemplating.

\section{Nascent net.art and Internet Utopianism}

Lev Manovich's book The Language of New Media, published in 2001, is the product of 1990s internet culture, when the revolutionary conditions ascribed to production and knowledge distribution on the internet were considered to be part of a subversive medium that is well-regarded today as a "spectacle playground." During this moment, the unfettered naïvete of this epoch coalesced around a neoliberal impulse to "open source everything"the enthusiastic call for free capital, free information, and free desire resounded through the annals of cyberspace.

In the summer of 2018, New York City's New Museum, in conjunction with the non-profit online art publication Rhizome ${ }^{[3]}$ facilitated the exhibit "The Art Happens Here: Net Art's Archival Poetics," which canvassed net.art's variegated history. Many of the works featured in this show, excluding a few more contemporaneous post-internet caveats, blossomed from the period directly imbued or responding to what has been dubbed the "California ideology," or the early internet utopianism that, lauding the democratic anonymity of the Web, extolled the ethos of Peter Steiner's 1994 New Yorker cartoon, professing that "[o]n the Internet no one knows you are a dog."

These sentiments are historically rooted, as Fred Turner's book From Counterculture to Cyberculture (2006) markedly traces. The military-industrial complex's ARPANET - the first virtual network to implement the TCP/IP protocol suite-and cybernetics are endowed to a counterculture comprised of Stewart Brand's ethos of the Whole Earth Catalog, the New Left, Buckminster Fuller's systems theory, Ken Kesey and the Merry Pranksters/1970s psychedelic music culture, and the back-to-the-land commune movement. If the "California Ideology" found its most marked proponents in Wired.com, it found polemic responses in the nettime mailing list, a net.art hub where Barbook and Cameron's critique of "dotcom neoliberalism" was circulated for debate.

In tracing the historical trajectory of tactical media, net artist collective Entropy8Zuper!'s skinonskinonskin (1999) illuminates this early romanticism. A series of digital love letters between Auriea Harvey and Michaël Samyn, the duo comprising Entropy8Zuper!, skinonskinonskin documents the couple's early romantic exchanges via Flash (in audio, text, and images), which took place in 1999 on hell.com, artist Ken Aronson's website that had a "reputation for using the Internet in unique ways that tended to confound their viewers" (Carey 2011, 145). Harvey and Samyn 


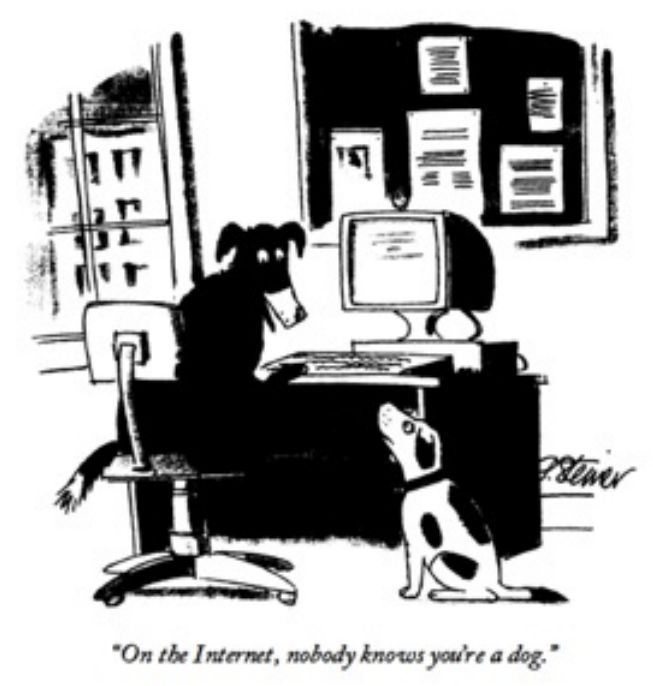

Figure 1: Peter Steiner (The New Yorker, July 5, 1993)

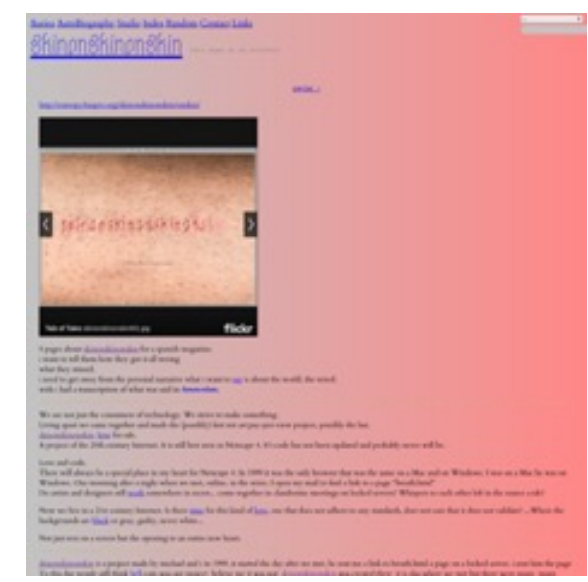

Figure 2: Auriea Harvey and Michaël Samyn [entropy8zuper], "skinonskinonskin" (1999) originally made these love letters (twenty-five in total) available to paid subscribers - viewers could trace the pair's burgeoning intimacy despite geographical distance.

Coincidentally, Auriea Harvey and Michaël Samyn, presciently wary of the capitalist vigor they felt encroaching upon the net.art terrain, abandoned net.art for videogame design in the early 2000 s. Their exchange, skinonskinonskin, remains not only a relic documenting two artists' blossoming love but, more importantly, is an epochal testament to the performance of sincerity online that flourished with playful innocence, conterminously supplementing the collective imagination of utopian promises accompanying seamless bandwidth, online freedom, and global intelligence. Unaccompanied by the angst of total surveillance and untethered to the customizable commoditysubject nature of a digital market probing the affective virtual landscape for any emotional pulse, this work is emblematic of an epochal blindness towards those online eros-profiteers to come (e.g. dating websites and apps such as Tinder and company).

Beginning in 1995, nettime-Geert Lovink and Pit Schultz' enormously influential listserv-stimulated the burgeoning "net.art movement," coined the term "tactical media" and pioneering related collectives that include Rhizome (1996-present), Fibreculture (2001-present), and Blast (1995-1998), while providing a virtual online salon for critical discourse on political internet-related happenings and organizing conferences such as Hacklt (Amsterdam), the Chaos Computer Congress (Berlin), and the Ars Electronica Festival (Linz). Thus, the early net art landscape was framed not solely by callow naïveté but, also, by great debates regarding the future of the internet and new media's place in it. Political experiments and various Internet-based parties, such as the 5 star movement, Pirate Party, Partido X, drew on the powers of these new socio-technical structures in order to produce massive processes of participation and deliberation (Terranova in MacKay et al. 2014, 392). For instance, Vuk Cosic, Heath Bunting, Alexei Shulgin and Josephine Bosma posed "net.radio" as an early tactical media resource, virtualizing the anarchic disposition of its forefather, "pirate radio," while spearheading both what was quite possibly the first major case of streaming media (Lovink 2002, 96) used to circumvent censorship far before Napster or the Piratebay. Here we also can trace the genesis of proto-accelerationist discourse, as new media enacts the political deployment of hypercamouflage, "a total withdrawal from the perception of friends and a dissolution into the enemy" (Negarestani 2008, 241) so as to lead to systematic breakages from within a system. 
This preliminary divide, between untainted utopianism and weaponized tactical appropriation, also informs the archive that is Starrynight (1999) - a landmark interface compiling Rhizome's listserv archives-which Mark Tribe created in consortium with Alexander Galloway and data visualization scientist Martin Wattenberg.

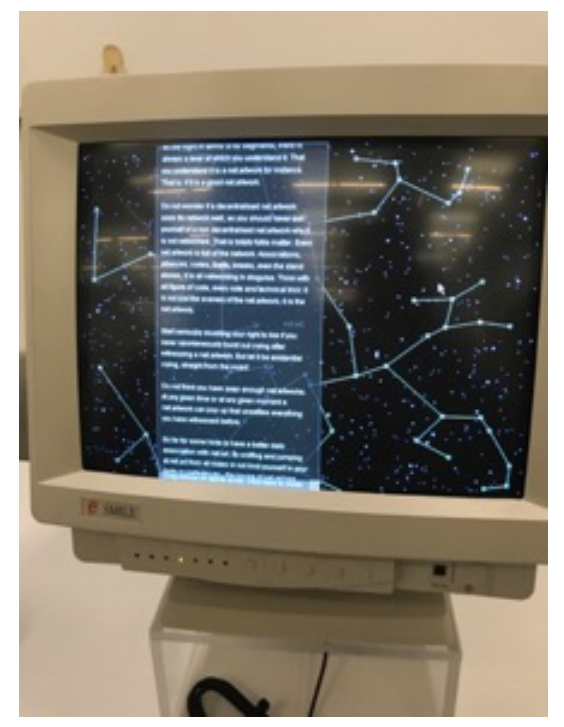

Figure 3: Mark Tribe, Alex Galloway and Martin Wattenberg, "StarryNight" (1999)
The database is an interface that references van Gogh's 19th century masterpiece and (first order) cybernetics systems theory; as a textual archive, each of the constellation's stars corresponds to one of the amaranthine archival texts. Developed via user-aggregation, Starrynight's constellations could not only be mapped but also expanded, as the archive was an open-source network where anyone could create a star by contributing to it. These impressive annals also speak to the pedagogical and organizational vigor of decentralization.

What I have tried to show is that the interval of nascent net.art and email listservs is in parallel with an early moment of internet counter-culture invested in biopolitics, sensation, and appropriative use that

often revolve around discourse related to sociality online. For further evidence, consider the prevalence of online avatars and massively multiplayer online role-playing games/platforms such as World of Warcraft, Everquest, and Second Life, which net artists like Eva and Franco Mattes utilized to traverse sociability and the subject's irreducible specificity, the "means by which the matter of the senses becomes general within a collectively lived situation" (Berlant 2011, 53).

Since the advent of the World Wide Web in April 1993 and the "new technologies" of computing and interactivity, which were then just emerging in all areas of everyday life, the novelty of this interactive environment has largely faded. Instead of the woefully misplaced optimism of the McLuhan-crazed "California Ideologists," a more appropriate adage would now posit the transfiguration from utopic cyberspace towards a "digital enclosure" emphasizing the interactive stronghold of networked devices that record everything that takes place upon theminformation is simultaneously stored, processed, and parsed. As Wendy Chun has remarked in Updating to Remain the Same, the displaced anonymous and empowering spaces of freedom, "in which no one knew if you were a dog" have seen a shift in the mid-to-late 2010s, "when the Internet was commonly conceived of as a space of total surveillance or as a privatized space of social media" $(2016, \mathrm{xi})$.

\section{On the Antagonism of Machinology}

As aforementioned, Paul Virilio insisted that, since World War II, we have been living in the state of "total war" or "pure war" between technology and humanity-subsequent sympathetic theorists and media historians have pointed to an intrinsic relationship between the invention of the atomic bomb, cybernetics, ARPNET, the computer and the rise of mass media (Lovink 2002, 309). As James R. Beniger argues in The Control Revolution, any such positivist discourse that endeavors to define the social effects of technologies based on network architecture needs to be qualified by the social conditions that prefigured and fostered the adoption or development of a 


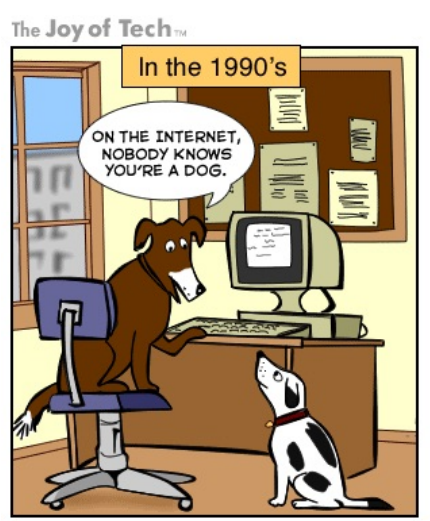

2013 Geek Culture

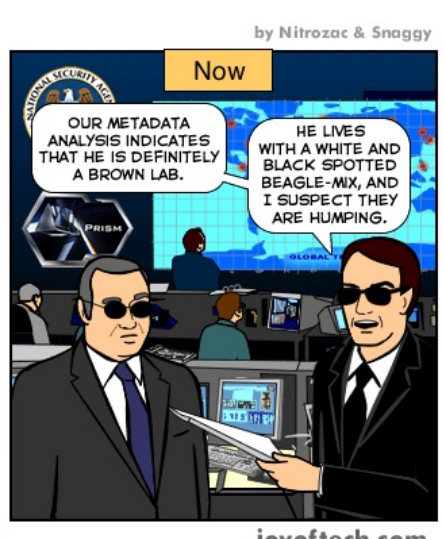

joyoffech.com
Figure 4: Liza Schmalcel and Bruce Evans (The Joy of Tech, 2013) particular technology $(1986,408)$. Thus, in The New Spirit of Capitalism, Boltanski and Chiapello account for the world of connexion, where the development of technologies that enable effective real-time longdistance control has to balance multiple priorities (1999, 296). Drawing from Michel Crozier and Hervé Serieyx's 1994 study "Du management panique à l'entreprise du XXle siècle" ("From Panic Management to 21st Century Business"), Boltanski and Chiapello denote two major options for such development: either towards a thematic of action devoid of a subject or towards "neopersonalism." While the former emphasizes the anonymous order

of the id and self-organization, the latter is dominant due to its normative, ethical dimension. Thus, the contemporary virtual "swarm" is preoccupied with the neoliberal obsession of "entrepreneur of the self" that Foucault outlined in The Birth of Biopolitics (1970).

In the wake of "exhibition value," Benjaminian "cult value" - much like aura - has not disappeared but, instead, remains as a central condition of contemporary commercial culture, stilted on "neopersonalism," German psychologist William Stern's multiplex definition of the unitas multiplex (2010). "Neopersonalism" fittingly describes the performativity afforded by hypermedia of the early aughts, such as Facebook, Twitter, YouTube, online polls, and other social platforms that indulge the simulation of user-empowerment (Vaidhyanathan 2018, 165). Accordingly, nothing better characterizes the new condition of objects and even of the human body in the era of fulfilled capitalism than exhibition value (Agamben 2007, 90). As Rosalind Krauss prefigured in "Video: The Aesthetics of Narcissism," the essence of "social media" and "video blogging" is not its ostensible content but exhibiting/performing oneself as such; this allots the interactive performer a continually renewable image (1976, $55)$.

Luc Boltanski and Eve Chiapello further trace the rise of automation and robotics in conjunction with networkbased post-Fordist work structures and "cool capitalism" (e.g. Apple and Ben and Jerry's), which, superficially, appear devoid of the standard formal trappings of bureaucratic authority. The "new spirit of capitalism" is bolstered by the rise of the "liberated enterprise" of control, which has become internalized in each employee, who "shares the dream of the leader," and is externalized in the consumer's Hayekian neoliberal mantra that "the customer is always right." (1486). How, then, can this pernicious "new spirit" be affrayed?

Like the Situationists combatting "the society of spectacle" via psychogeography (the dérive), Virilio extolled a "new consciousness" to combat the technologic "pure war" undergirding a new kind of consumer-social transformation bolstered by circulation and stasis rather than the (old Marxist) terms of state power and class struggle. However, in moving from a defensive strategy to an offensive position of "rebellion," Virilio incautiously endeavored not to reappropriate the products of a technological society, as in Guy Debord's "détournements," but, instead, to democratize the ideology involuntarily released by weapons of communication. For Virilio, only by extrapolating the destructive bent inherent in modern technology (to bring out its most pernicious negative effects) could its "riddle be unraveled" (Virilio and Lotringer 2001, 33-34). Consequently, for Virilio, technics harbor an irreducible and necessary "extimacy," whereby a guiding psychic apparatus is contained within the media artifact. 
While this aptly foreshadows the trajectory of Antoinette Rouvroy and Bernard Stiegler's work on "algorithmic governmentality," or the epistemological and semiotic normative metabolism directed by the "regime of digital truth"-e.g, predictive processing algorithms' self-actualization-it also glosses over the Janus-faced nature of machinology, as this antagonism between destratification and composition becomes exacerbated in Deleuze and Guattari's work on "abstract machines." If Virilio's rendering of machines is enveloped by their "expressive function," a techno-determinist reading whereby militarism functions as an asymptotic bottleneck, it concurrently prompts an intermediary position where the processual becoming of history is nestled between a materialist real and an idealist imaginary.

As Paul Patton underscores, in A Thousand Plateaus Deleuze and Guattari follow Paul Virilio's "apocalyptic or millenarian" conception of the present "as one in which the worldwide war machine now finds its object not in the conduct of war but in the maintenance of an 'absolute peace' of terror or deterrence directed at an 'unspecified enemy"' (Patton in Somers-Hall 2019, 217). According to Deleuze and Guattari, the economic function of capital presents itself vis-à-vis the materialization of military technologies that are molecular, distributed and programmable. This geopolitical vantage of the worldwide "abstract war machine" may have aptly described Cold War politics through the end of the 1970s but, today, appears less convincing in the aftermath of the Soviet Union, where the rise of China is concurrent with the re-emergence of archaic war machines fueled by religious extremism and supplemented by asymmetric conflicts between military and paramilitary forces (e.g. the contemporaneous conflict between the Turkish military and the Kurdish-led YPG). This conception of mid-to-late $20^{\text {th }}$ century capitalization demonstrates how the global axiomatic of capitalism was conceived of as performing technoscientific "blackmail" that needs no "qualified enemy" but, instead, materialized under micro-sociological phenomena such as "organized insecurity or molecularized, distributed, programmed catastrophe" (Deleuze and Guattari 1987, 467).

Virilio's determinist drift is also manifest in Deleuze and Guattari's discussion of the interwoven evolutionary destinies of the wasp and the orchid. Here, we see the unfolding of how two heterogeneous phyletic genealogies progressively intertwine into networks of mutual influence and codependence: "[ $\mathrm{t}] \mathrm{he}$ wasp and the orchid are in a perpetual state of mutual presupposition, as their parallel evolutionary courses enact each other's affordances, drawing them forth into actualization" (Wilson 2019, 87). While overdetermining the milieu's univocal movement may appear as an overwrought vestige of vitalism, Virilio, alongside Deleuze and Guattari, illuminates how the directive structural coupling of ecosystems, transversally organized, meshes interactions between self-organizing systems, which will become constitutional to the introduction of second order cybernetics' negative feedback. As each milieu is decoded by others while, simultaneously, enacting its own processual decoding, it results in a "characteristic rhythm of the ecosystem" (Wilson 87), where we see how representational thinking in terms of difference is slowly outpaced by the terms of totalization. Consequently, Virilio's "total war" proclaims how Norbert Wiener and the widespread introduction of computers is constitutionally poised for the destruction and erasure of utopian representational thinking, which is constituted by an all-determinate provisional present. Fredric Jameson has extended this position, claiming that Ernest Callenbach's Ectopia, published in 1975, was the last great utopian text and, thereafter:

we have the free-market deliria of cyberpunk, which assumes that capitalism is itself a kind of utopia of difference and variety... this failure of imagination on the left can be attributed to the assumption that computers are enough to 'take care' of totalization: that the well-nigh infinite complexities of production on a global scale, which the mind can scarcely accommodate, are mysteriously...resolvable inside the computer's black box and thus no longer need to be dealt with conceptually or representationally. (Jameson 2012, 125) 


\section{Post-Internet Art}

However, if utopia-as-representation is deprived of its political praxis, utopia-as-confrontational-technique continues to be invigorated by politically-poised post-internet artists who insist on its viability. For instance, Sister Unn's (2012), an installation by Bunny Rogers and Filip Olszewski, attempts to validate this idealist battle. Based on a mysterious storefront that led passersby to an equally enigmatic website, exemplifying the links between real and virtual space, the duo behind Sister Unn's (2012) converted an abandoned building to an enigmatic flower shop on a well-to-do shopping street in Queens, New York.

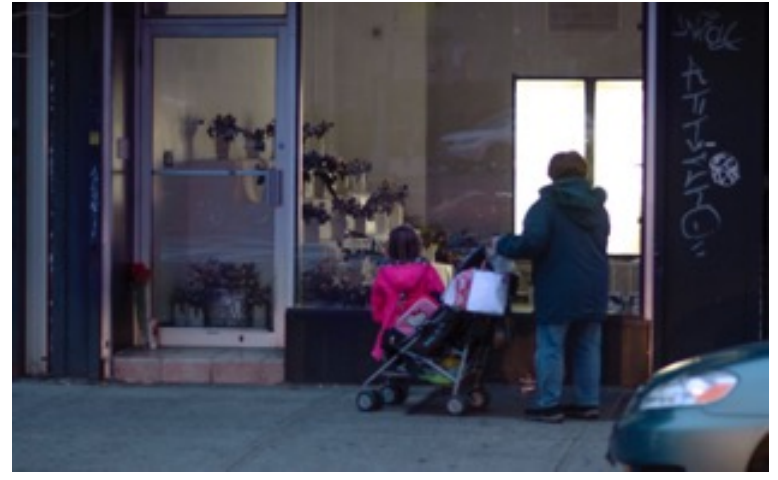

Figure 5.a: Filip Olszewski, Sister Unn's (2012)

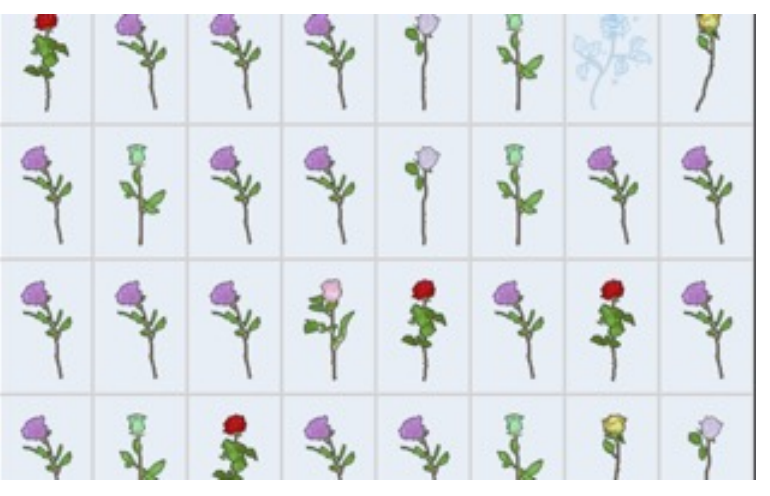

Figure 5.b: Filip Olszewski, Sister Unn's (2012)

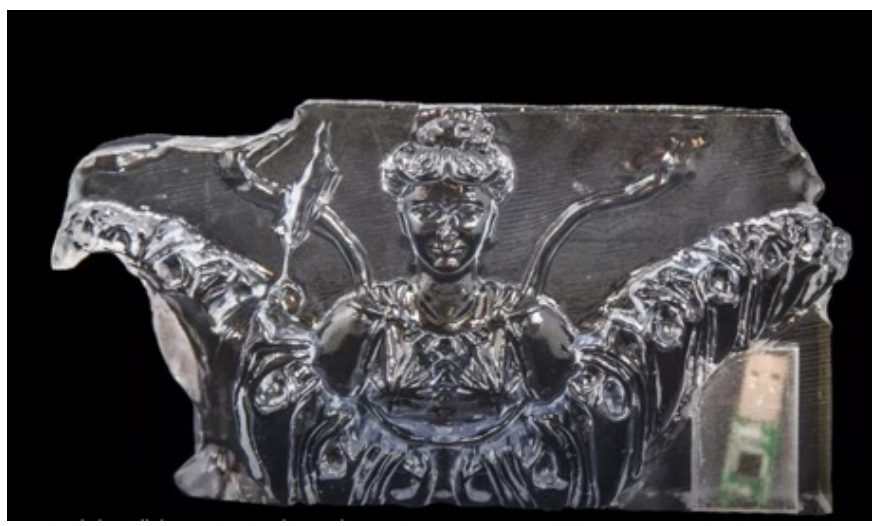

Figure 6.a: Morehshin Allahyari, "Material Speculation : ISIS-
Never opened to the public, pedestrians peered into the window to see drying flowers lining the abandoned shop's shelves and a single rose encased in a block of ice in an illuminated freezer. The work's title is from characters in "The Ice Palace" (1963), a classical literary work of Norwegian author Tarjei Vesaas that examines a community's process of mourning. The parallel site, www.sister-unns.com, features a digital rose database, professing catharsis by way of pastiche for a virtual tragedy.

Brooklyn-based Iranian post-internet artist and researcher Morehshin Allahyari's work is less involved with the virtual sphere and more materially bound. Material Speculation: ISIS (2015-2016) is a project that uses 3D printing to recreate the twelve artifacts that were destroyed by ISIS in 2015's Mosul Museum bombing(s). Each artifact also contains a USB drive or memory card that contains files of her research, as exemplified by Marten (2016), which contains an SD card that includes an admixture of Allahyari's research and process.

Allahyari's Marten responds to "digital colonialism," as the SD card is not to be accessed by Western audiences and art institutions. Rather, Allahyari has set a long-term goal of positing her pieces in an institutional archive within the Middle East so as to facilitate a regional commons in cultural and geographic propinquity to the site(s) of eradication.

The question remains, however, what is the relationship between such affective work and control and does the former not simply bolster the 
Marten" (2015-2016)

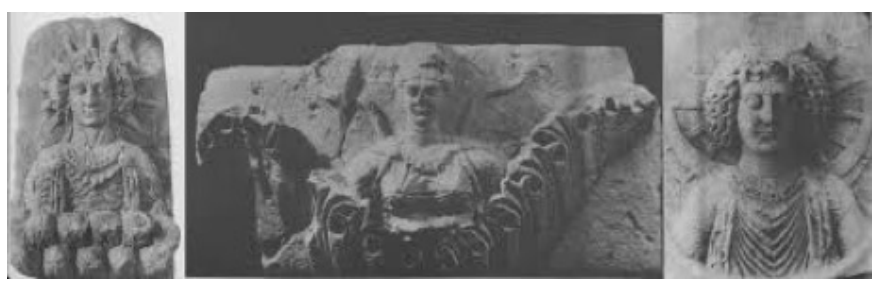

Figure 6.b: Morehshin Allahyari, "Material Speculation : ISISMarten" (2015-2016) latter? Chris Andersen's ever-popular 2008 article "The End of Theory" posed that Big Data's analyses, which enable prognostication, make hypothetical models of theory unnecessary: correlation wins over causation and the question of why takes a back seat to what. By even attempting to contemplate surveillance in the era of Big Data, we find that it is hard to even conceive of the magnitude of the data being collected, let alone attempt to make sense of its contents. In the province of automated data-

mining, sorting and sentient analysis reframe sense-making according to the narrow definition of finding patterns, trends, and correlations between elastic hyper-priors. Thus, a new digital divide is born between those with access to programming algorithmic intelligence (or, more specifically, access to programming their inputs) and those without. The likelihood for a participatory legislative process where we are all involved in the "nudging" of algorithmic prudence, as lauded by Catheirne Malabou in Morphing Intelligence, appears to be more and more untenable, as we see "identity play, community building, and gift economies" usurped by "a more privatized, profitdriven model" (Nakamura 2007, 3; 31).

Bunny Rogers and Filip Olszewski's project gestures towards the database logic as a symbolic dominant without accounting for its truly all-encompassing absolutism. Allahyari's pedagogically inclined work is steeped in a kind of idealism, that epistemophilia can counter the state "war machine" and separate itself from its lineal grip. With the introduction of Facebook's "free basics Internet.org" - a stratified, affordable-access internet for less-developed countries - and an FCC order repealing net neutrality in the United States (in effect as of June 11, 2018), the "payto-play" internet model is becoming increasingly evident. Facebook's story, as Siva Vaidhyanathan describes, comprises the hubris of "good intentions, a missionary spirit, and an ideology that sees computer code as the universal solvent for all human problems" $(2018,3)$, or the actualization of Jameson's "black-box" postrepresentational totalization. Facebook is not alone in the deterioration of democratic and intellectual culture around the world - the platform is merely another signifier of the dangers of Silicon Valley's widespread cultural commitment to "data driven decision-making and logical thinking" (Vaidhyanathan 4), positioning global market orientation as a parallel strategy in supplementing its labor force.

If post-internet art simply regurgitates the tendencies of modulation and predictive control, sans net.art's optimistic utopianism, it is all the worse for it. After all, the time during which the Internet could "reasonably be viewed as a possible alternative space where egalitarian utopias might be constructed by plucky resistance fighters of any age or gender is long over" (208) writes Lisa Nakamura in Digitizing Race. Thus, where do we situate the political responsibility for culturally-oriented visual art, then? Do we consolidate early internet art's discourse as simply idealistic, or is there a place for tactical utopian methodologies?

\section{Reflecting on Accelerationism and Hypercamouflage}

Geert Lovink and other critics of the global Empire uphold that, while informatic networks are indeed important, at the end of the day sovereign powers matter more, paving the way for accelerationism. A second school of thought, as evinced by Alexander Galloway and Eugene Thacker's The Exploit (2007), proposes that networked post-Fordist economies and the new millennia of internet protocols are "more of the same," whereby the new language of 
control is IP/TCP. Taken to its final premise, Lovink's position poses that we can challenge the data miners at their own game, whereas Galloway and Thacker's position posits that we will always be underfunded and understaffed. Whereas Lovink's "tactical media" seeks to reterritorialize the internet, Galloway poses that there is no going back. What, then, is the progressive political model for technoscience, the humanities, and the arts?

Galloway's admonition warns us that coopting the tools of the digital divide to usurp the terms of platform capitalism is not sufficient. Let us recall that Nick Srnicek and Alex Williams' 2013 Accelerate Manifesto: For an Accelerationist Politics originally proffered accelerationism as a radical leftist political practice that would take advantage of technological and scientific advances made possible by capitalist society and push them further, towards a post-capitalist future. This manifesto has been blemished by the neolibertarian right of the Dark Enlightenment who have eagerly co-opted accelerationism, so that the strategy of hypercamouflage simply seems less viable. As Galloway adeptly describes in his article "Brometheanism" (2017), Srnicek's follow-up book to the Accelerationist Manifesto, Inventing the Future (2015), is plagued by another such paradox. While it denounces the "folk politics" of Occupy, the Zapatistas, Tiqqun, localism, and direct democracy in favor of a "planetary hegemony," it also invigorates the (anti-work) polemic focused on the universal basic income (UBI) and shortening of the work week. Galloway reminds us (pointing to Marx's analysis of machines in Das Kapital) that, while automation changes work for some, it increases work for others. Accelerationism presents a spectrum of problems that Srnicek and Williams do not solve in posing an "ecology of organizations" as "the proper form of organization" (162-163). Žižek often likens post-capitalism to "capitalism with a friendly face" and Srnicek and Williams' model of post-capitalism in Inventing the Future fits this description.

Srnicek's position denotes that platform capitalism has "inbuilt tendencies to move towards extracting rents by providing services" $(2016,162)$, such as cloud platforms, infrastructural platforms, or product platforms. It is more likely, however, that any emergent "post-capitalist" economic system will be highly flexible and adaptively implement extra- economic factors into its processual exchange, including a mix of universal basic income, citizen score systems, decentralized blockchain infrastructures, and the management technologies developed in platform capitalism. Whether this ought to truly be termed "post-capitalist," as theorists like McKenzie Wark assert, is disputable, for Marx's description of the bifurcation between "absolute surplus-value" and "relative surplus-value" already accounts for this fissure. As opposed to "absolute surplus," which relies on increased work hours and a corresponding broadening of production, "relative surplus-value" is generated by improvements in technology, workplace organization or appropriative labor productivity (e.g. the monetization of debt), "arising from the curtailment of the necessary labour-time" (Appadurai and Alexander 2019, 110) and the obfuscation of regular temporal ordinance.

This progression, or, at best, epistemic rift (rather than full-fledged breakage) is calcified by the ability of predictive technologies to account for differential elasticity. Such is the case in elastic graph bunching for facial recognition software and other biometric devices, or with actuarial finance. With neural nets and machine learning, the "storage-retrieval" mode of the database is increasingly becoming displaced by phylogenic compossibility, where different phylogenetic paths simultaneously evolved under various "inputs."[4] Perhaps, as Davor Loeffler predicts, after companies have "adopted technologies that originally were developed for the public, the public will re-adopt and re-socialize the management technologies enhanced in the competition between the companies exploiting the niches in virtual space" $(2018,43)$. However, Srnicek's brand of accelerationism fails to posit any specific viable technological intervention, merely maintaining that the cross-subsidization bolstering the internet's public-facing infrastructure will end despite wealth and income disparities will, in turn, be replicated vis-à-vis access inequalities. 


\section{Conclusion: Navigating the Denial of Epistemic Access to Worldmaking}

Walter Benjamin once invigorated the camera with an ability to reveal the "optical unconscious," or the punctum caecum/blind spot of contact, distancing perception from what is immediately visible (Didi-Huberman and Hartz 2004, 90). Similarly, just as "we discover the instinctual unconscious through psychoanalysis" (Benjamin 37), datamining reveals a kind of collective digital unconscious foreclosed to naked observation. I have tried to make the case that, with the possibility of enlisting algorithmic governmentality to discern the masses' patterns of behavior, digital psychopower displaces biopower (Han 2017, 127) while co-opting techniques of resistance. As with the "internet of things," those autonomous transmitters and digital agents that send information/meta-data to one another, are bringing forth what Stiegler terms "hyper-control," defined by the genesis of psychotechnologies and established by generalized automatization (Erkan 2019, 231), to completion. This takes us one step further than the control-through-modulation thesis of Deleuze's "control society" (Stiegler in Koch et al. 2019, 36).

As the New York Times disclosed in 2012, we are now in an era where data-mining allows Target to "...figure out if out if a customer is pregnant, even if she didn't want us to know," (Duhigg 2012) and, thus, it would appear that internet art, new media art and, by extension, art and the humanities, overall, are tasked with new responsibilities that don't solely point inwards (towards the affective self/subject) but to re-appropriate, challenge, and weaponize. If the constitution of the human is inherently technological, one post-hermeneutic proposal to grapple with control after decentralization is to retreat from the teleological models of internet utopianism, transhumanism, or accelerationism and enact the aesthetic tools of history against their necessarily ideologically-furnished semblance.

For instance, François Laruelle, in his analyses of James Turrell's light sculptures and aquatints, uses the term "photic materiality," describing how Turrell's light, non-cosmic and non-ontological, does not orient the viewer but, rather, performs experiments on perception, retraining it according to alternative logics. This mode of perception unilaterilizes - "light acts instead...like a drive that has its own 'subjectivity,' or like an a priori force" (Laruelle 1991, 1). Here, neither artist, viewer, or critic is privileged with a position to arbitrate Turrell's aesthetic experiment(s) but, rather, all three members are rendered strictly identical. Laruelle's non-aesthetic thesis is utopic insofar as it positions the real in parallel with the world, whereby utopia is defined as "non-place," immanent only to itself, a method in sharp contrast to Jameson's "bygone world" because the noumena is not only denied interaction, as in the Kantian model, but also epistemic access.

Laruelle's metaphysics of the Real is like "Schrödinger's cat" in the sense that it encompasses a multiplicity of states in a unified theory and, simultaneously, a multiplicity of theories in a unified state, despite the fact that the full superposition of states is foreclosed to full epistemic access. Nonetheless, studying the Real "that is approximated" can result in the analogical and unconscious capture of perceptual truths. Considering perceptual truths through an aesthetic partition, Laruelle celebrates James Turrell's ethereal light sculptures, which comprise the duality of thought/Real. Laruelle calls this the "labor of the radical dyad" (2013, 91-92), as Turrell's installations dualize light by casting it in visual and haptic registers. Turrell's labile perceptual dynamic projections do not deconstruct or dispense with binaries such as appearance and truth.

The philosophical consequences of perception as such detaches the materiality and metaphoricity of light from its association with reason and revelation. Can the same be applied to predictive processing algorithms? Confronting technical and optical systems through rigorous scientific observation-that is, understanding them through their 
material nodes and probabilistic linealities - affords a political advantage when democratized to the commons. In Cinema 2 (1989), Deleuze appoints cinema and the arts with the responsibility to facilitate the representation of a "missing people": Deleuze's affirmative political aesthetic theory upholds that art must initiate a fold in the distribution of the sensible. However, given that the post-cinematic terrain of virtuality transfixes and exchanges data-capture as conflated with the aesthetic experience, this affirmation, or "suspended meaning," has been coopted by the intermedial age of symbolic efficiency, predictive probabilistic measure, and plastic reappropriation ad infinitum. Consequently, what was once considered the positive use of common experience qua resistance, or sensorial points for informatic input, can no longer be regarded as a gesture of instrumental rationality, but, instead, is circumscribed to the periphery of the standard media mechanization's unconscious libidinal thanatropism(s).

Thus, if are to treat media materially, we must parse reticulated screens as both software and hardware, prewritten in computational language and exacted through circuit boards, central processing units, interface cards, and embedded systems. Bernard Stiegler's work, for example, is always accompanied by praxis in addition to theory. From Plaine Commune, Stiegler's recently inaugurated "contributory learning territory," to the 2020 League of Nations macroeconomic "Internation.World" initiative, Stiegler advocates for direct political legislative action.

Parsing digital artifacts, the "observer-effect" cannot be discounted-the observer and/or instruments of observation are also atomic systems that have non-trivial effects on that which they observe (Fardy 2019, 81). If we are to seek a neganthropic commons carved around the commons, denying the entropic asymptote of predictive catastrophism, we must approach systems of hypercontrol as a "generic science," or that which is immanent visa-vis the real, rather than striving for a purely philosophical approach (the transcendental vis-à-vis the real). This means a principle of unity, where we each fluently "speak" at least one computer language, in addition to a natural language. Any Marxist philosopher worth their salt recognizes the folly of simple diagnostic musings, for it is altogether more valuable to trace autopoietic modalities alongside their historical contingencies, while conceding that these two are not necessarily parallel.

\section{Bibliography}

Agamben, Giorgio. Guy Debord and the Situationist International: Texts and Documents. MIT Press, 2004.

Anderson, Chris. "The End of Theory: The Data Deluge Makes the Scientific Method Obsolete." Wired, Conde Nast, 26 Jan. 2018, www.wired.com/2008/06/pb-theory/.

Andrejevic, Mark. Infoglut: How Too Much Information Is Changing the Way We Think and Know. Routledge, 2013.

Appadurai, Arjun and Neta Alexander. Failure. Polity, 2019.

Barber, Benjamin R. Strong Democracy: Participatory Politics for a New Age. University of California Press, 1985.

Beniger, James R. The Control Revolution: Technological and Economic Origins of the Information Society. Harvard University Press, 2009.

Benjamin, Walter, and Michael W. Jennings. "The Work of Art in the Age of Its Technological Reproducibility." Grey 
Room, vol. 39, 2010, pp. 11-37., doi:10.1162/grey.2010.1.39.11.

Berry, David M., and Alexander R. Galloway. "A Network Is a Network Is a Network: Reflections on the Computational and the Societies of Control." Theory, Culture \& Society, vol. 33, no. 4, 2015, pp. 151-172., doi:10.1177/0263276415590237.

Berlant, Lauren. Cruel Optimism. Duke University Press, 2011.

Bert, Jean-François. "Ce qui résiste, c'est la prison. Surveiller et punir, de Michel Foucault," Revue du Mauss, vol. no 40 , no. 2, 2012, pp. 161-172.

Boltanski, Luc, et al. The New Spirit of Capitalism. Verso, 2018.

Carey, Brainard. New Markets for Artists: How to Sell, Fund Projects, and Exhibit Using Social Media, DIY Pop-Ups, eBay, Kickstarter, and Much More. Allworth Press, 2011.

Chun, Wendy Hui Kyong. Updating to Remain the Same: Habitual New Media. The MIT Press, 2016.

Crary, Jonathan. 24/7: Late Capitalism and the Ends of Sleep. Verso, 2014.

Daly, Kristen. "Cinema 3.0: The Interactive-Image." Cinema Journal, vol. 51, no. 1, 2010, pp. 81-98.

Deleuze, Gilles. Negotiations: 1972-1990. Columbia University Press, 1997. . Foucault. University of Minnesota Press, 2016.

. A Thousand Plateaus, trans. Brian Massumi. University of Minnesota Press, 1987.

. Cinema 2, trans. Hugh Tomlinson and Robert Galete. University of Minnesota Press, 1986.

Didi-Huberman, Georges, and Alisa Hartz. Invention of Hysteria: Charcot and the Photographic Iconography of the Salpêtrière. The MIT Press, 2005.

Duhigg, Charles. "How Companies Learn Your Secrets." The New York Times, The New York Times, 16 Feb. 2012, www.nytimes.com/2012/02/19/magazine/shopping-habits.html.

Elsaesser, Thomas. "Contingency, causality, complexity: distributed agency in the mind-game film." New Review of Film and Television Studies, vol. 16, no.1, 2018, pp. 1-39.

Erkan, Ekin. "Psychopower and Ordinary Madness: Reticulated Dividuals in Cognitive Capitalism." Cosmos and History: The Journal of Natural and Social Philosophy, vol. 15, no. 1, 2019, pp. 214-241.

Fardy, Jonathan. Laruelle and Art. Bloomsbury Academic, 2019. 
Foucault, Michel. Discipline and Punish. Vintage Books, 1975.

Galloway, Alexander R. "Laruelle and Art." Continent., no. 2.4, 2012, pp. 230-236.

. Protocol: How Control Exists after Decentralization. MIT, 2006.

. "Brometheanism." Culture and Communication, 16 June 2017, cultureandcommunication.org/galloway /brometheanism.

Galloway, Alexander R., and Eugene Thacker. The Exploit: A Theory of Networks. University of Minnesota Press, 2007.

Galloway, Alexander R., et al. Excommunication: Three Inquiries in Media and Mediation. The University of Chicago Press, 2014.

Han, Byung-Chul, and Erik Butler. In the Swarm: Digital Prospects. MIT Press, 2017.

Hardt, Michael, and Antonio Negri. Empire. Harvard University Press, 2000.

Jameson, Fredric. "In Soviet Arcadia." New Left Review, vol. 75, 2012, pp. 119-127.

. Postmodernism, or, the Cultural Logic of Late Capitalism. Verso Books, 1991.

Kittler, Friedrich. Gramophone, Film, Typewriter. Stanford University Press, 2006.

. Discourse Networks, 1800/1900, trans. Michael Metteer. Stanford University Press, 1990.

Koch, Gertrud et al. Machine. University of Minnesota, 2019.

Laruelle, François. The Concept of Non-Photography, ed. Robin Mackay. Urbanomic, 2012.

. Philosophy and Non-Philosophy, trans. Taylor Adkins. University of Minnesota, 2013.

. "A Light Odyssey: La découverte de la lumière comme problème théorique et esthétique," trans.

Alexander Galloway. Le Confort Moderne, 1991.

Lovink, Geert, and Ned Rossiter. Organization after Social Media. Minor Compositions, 2018.

Lovink, Geert. Dark Fiber: Tracking Critical Internet Culture. MIT Press, 2003.

Mackay, Robin et al., \#Accelerate: The Accelerationist Reader. Urbanomic, 2014.

Malabou, Catherine. Morphing Intelligence: From IQ Measurement to Artificial Brains. Columbia University Press, 2019. 
Manovich, Lev. "Database as Symbolic Form." Convergence: The International Journal of Research into New Media Technologies, 1 June 1999, pp. 39-60., doi:10.1177/135485659900500206. The Language of New Media. MIT Press, 2001.

McLuhan, Marshall and Barrington Nevitt. Take Today: The Executive as Dropout. Longman Canada, 1972.

Nakamura, Lisa. Digitizing Race: Visual Cultures of the Internet. University of Minnesota Press, 2008.

Negarestani, Reza. Cyclonopedia: Complicity with Anonymous Materials. re.press, 2008. . Intelligence and Spirit. Urbanomic, 2018.

Rouvroy, Antoinette, and Thomas Berns. "Gouvernementalité Algorithmique Et Perspectives D'émancipation: Le Disparate Comme Condition D'émancipation Par La Relation.” Réseaux, 2013, pp. 163-196.

Sey, Araba and Manuel Castells. "From media politics to networked politics: the Internet and the political process," in The Network Society, pp. 363-385. Edward Elgar, 2004.

Schutte, Nicola S., and Emma J. Stilinović. "Facilitating Empathy through Virtual Reality." Motivation and Emotion, vol. 41, no. 6, 2017, pp. 708-712., doi:10.1007/s11031-017-9641-7.

Somer-Hall, Henry et al. A Thousand Plateaus and Philosophy. Edinburgh University Press, 2018.

Srnicek, Nick. Inventing the Future: Postcapitalism and a World Without Work. Verso Book, 2015.

Stiegler, Bernard. The Neganthropocene. Open Humanities Press, 2018. . The Age of Disruption. Polity, 2019.

Tiqqun. "The Cybernetic Hypothesis: Part IV." Short Circuit: A Counterlogistics Reader, edited by Jasper Bernes, 2012, pp. 70-88.

Turner, Fred. From Counterculture to Cyberculture: Stewart Brand, the Whole Earth Network, and the Rise of Digital Utopianism. The University of Chicago Press, 2008.

Vaidhyanathan, Siva. Anti-Social Media How Facebook Disconnects Us and Undermines Democracy. Oxford University Press, 2018.

Virilio, Paul, and Sylvère Lotringer. "After Architecture: A Conversation." Grey Room, vol. 3, 2001, pp. 32-53., doi:10.1162/152638101300138530.

. Pure War. Semiotext(e), 1983. 
Williams, Alex, and Nick Srnicek. \#Accelerate Manifesto: for an Accelerationist Politics. Gato Negro Ediciones, 2013.

Wilson, Alexander. Aesthesis and Perceptronium: On the Entanglement of Sensation, Cognition, and Matter. University of Minnesota Press, 2019.

Winston, Brian. Technologies of Seeing: Photography, Cinematography and Television. British Film Institute, 2009.

Žižek, Slavoj. "Edward Snowden, Chelsea Manning and Julian Assange: Our New Heroes | Slavoj Žižek." The Guardian, Guardian News and Media, 3 Sept. 2013, www.theguardian.com/commentisfree/2013/sep/03/snowdenmanning-assange-new-heroes.

. The Plague of Fantasies. Verso, 1997.

\section{Notes}

1. While "parricide" today is used to describe the murder of a parent, at the time the term was used to refer to the attempt to murder parent, older relative, or ruler.

2. The use of "aesthetic" here has Kantian roots, insofar as it refers to a kind of transcendental relativism that allows for no form of absolute; however, it more explicitly refers to the Hegelian mode of aesthetics, which is dependent on socialization and communal response to cultural artifacts.

3. The art publication Rhizome (hosted on Rhizome.org), founded by artist and educator Mark Tribe in 1996, ought not to be confused with the journal Rhizomes: Cultural Studies in Emerging Knowledge (Rhizomes.net).

4. This is, in fact, how AlphaGo, a Google DeepMind neural net defeated Ke Jie, the world's top Go player, in a three-game Go match.

\section{Cite this Essay}

Erkan, Ekin. "The Post-Human Media Semblance: Predictive Catastrophism." Rhizomes: Cultural Studies in Emerging Knowledge, no. 36, 2020, doi:10.20415/rhiz/036.e06 